\title{
APPLYING APPLICATION-BASED NEAR FIELD COMMUNICATION (NFC) PAYMENT SYSTEM FOR PUBLIC TRANSPORTATION IN INDONESIA (CASE STUDY OF PUBLIC TRANSPORTATION IN JAKARTA)
}

\author{
Nabila $^{1}$, Meilin Debora C. Hutauruk ${ }^{2}$, Abdullah Ade Suryobuwono ${ }^{3}$ \\ 1. STMT Trisakti, 2. STMT Trisakti, 3. STMT Trisakti \\ $\triangle$ Corresponding author : nabilabaros07@gmail.com
}

\begin{abstract}
Nowadays, a massive transportation payment system in DKI Jakarta is yet able to help the movement of public transportation easily and quickly. Card, as a payment device, is expected to be able to make people use public transportation instead of personal vehicle. However, the result is not as expected for until recently, this card hasn't reduced the difficulty of payment process. So, there are still a lot of people prefer to use personal vehicle. NFC is suggested as an application based system which can help people in ticket buying process and can identify the passenger in the public transportation. When NFC is used, it will automatically reduce the passenger's balance in accordance with the distance tariff that has been determined by the transportation company. In addition, a passenger can directly get the information of mode of transport. In this research, the authors conduct a qualitative study in which the data is obtained through literary review, interview method, and observation. The results of this research are; (1.) NFC System gives the easiness and comfort for the people in using public transportation; (2.) Some advanced countries that have applied NFC System are successful on helping the people in transportation activity; and (3.) NFC System makes a more simple payment transaction.

Keywords: Payment System, Ticketing, Near Field Communication (NFC), Public Transportation.
\end{abstract}

\section{Introduction}

Transportation in DKI Jakarta has an important role in supporting the activity of the passengers. Generally, transportation is divided into 2 types; personal transportation and public transportation. Sustainable transportation system is a system that can meet the sense of justice, namely by accommodating the needs of accessibility or demand for all users of the road to the safe and comfortable eisiensi; meet the level of natural resources, both in terms of the use of energy and resources of the utilization of the; can be managed in a transparent and participatory manner; as well as guarantee the continuity for future generations (Kadarisman, Gunawan, \& Ismiyati, 2017). However, the number of personal transportation and public transportation in

DKI Jakarta is not balanced. Most people prefer to use public transportation 
due to the slow and difficult payment system. The diagram below shows the passenger data for Commuter Line and Trans Jakarta:

Table 1. A Passanger Data of Transjakarta and Commuter Line

\begin{tabular}{|l|c|c|}
\hline \multicolumn{1}{|c|}{ Passenger Data } & $\mathbf{2 0 1 4}$ & $\mathbf{2 0 1 5}$ \\
\hline Trans Jakarta & 111.630 .000 & 102.950 .000 \\
\hline Commuter Line & 208.494 .094 & 279.733 .840 \\
\hline \multicolumn{2}{|c|}{ Source : (BPS Province of DKI Jakarta, 2016) }
\end{tabular}

Application-based payment system is one of the efforts made to reduce the problems of transportation in DKI Jakarta. The payment system currently used hasn't made it easy for the people using transportation. For the airlines, a tariff that is too low may jeopardize the sustainability of an air carrier's operations, while a tariff is too expensive may make it unaffordable for travelers to travel (Rafi \& Rifni, n.d.). There are a lot of people using card as a payment device, but it hasn't helped the people's movement in using public transportation. If services are received or is felt (perceived service) as expected, the quality of services and satisfying perceived good, so that it will impact raise the loyalty consumers. But if services they received is more lower than expected, the quality of services perceived bad that would have an impact reduce the loyalty consumers (Siregar, Manajemen, Trisakti, Manajemen, \& Trisakti, n.d.). Some disadvantages of using a card as a payment device are; (1) it is hard to top up the balance because it needs a special machine and (2) it is not safe, because the card cannot be block if it is lost, making it easy to be used by other people. In this modern era, most people use smartphone and there are many applications which can be used as a payment system, such as NFC (Near Field Communication). Below is the percentage of household that has a cellular phone: 


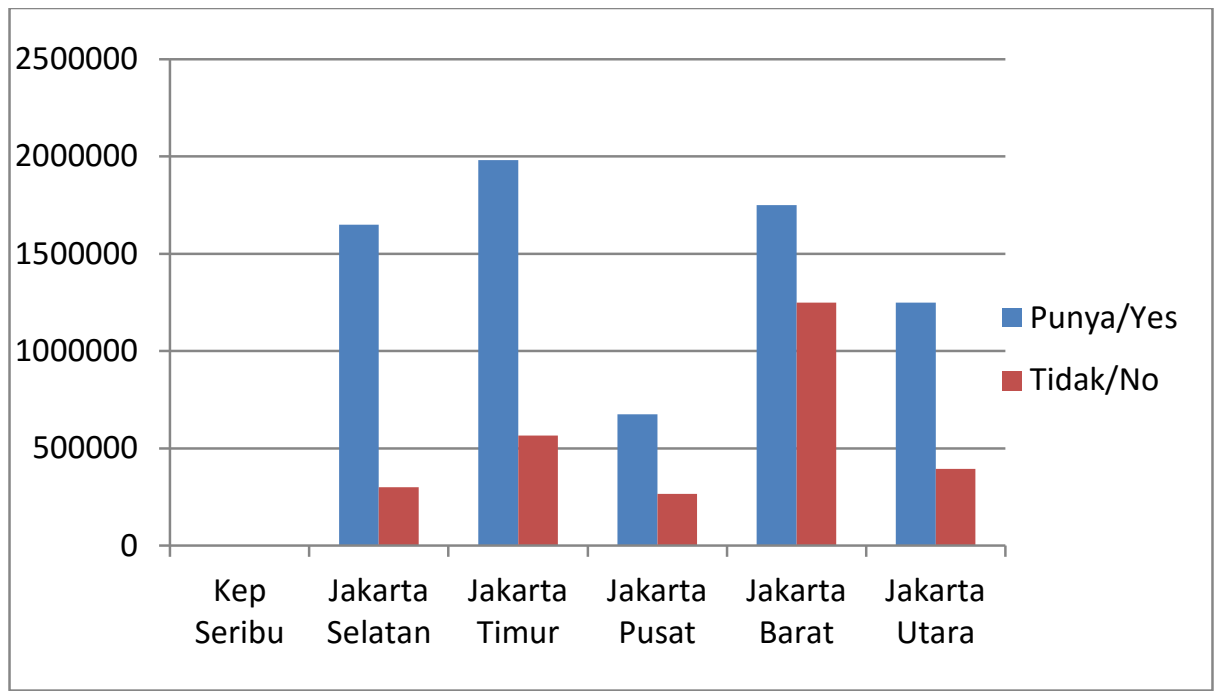

Figure 1. Percentage of Household that has Cellular Phone

Source : (BPS Province of DKI Jakarta, 2016)

The data above shows that there are a lot of smartphone users especially in Jakarta area. Smartphone also provides all kind of features including payment system, such as NFC (Near Field Communication). NFC is a standard device that enables smartphone and other devices to communicate when they are brought close. NFC works like RFID, but NFC has a shorter reach than RFID. NFC Application as a payment device has been applied in many countries. One of the advantages of NFC is that it makes it easy to do a transaction without credit card or prepay system. Development of transportation aimed to improve the service transportation service efficient, effective, reliable, quality, safe, affordable (K. Martono \& Marina, n.d.). The existence of NFC can reduce the problem of transportation in DKI Jakarta; especially for the payment system.

\section{Purposes}

The purposes of this research are:

1. To know the benefits of technology for public transportation in reducing the problems of transportation in DKI Jakarta,

2. To know the use of the application NFC (Near Field Communication) technology system in a few countries,

3. To know the potential of adopting NFC System in DKI Jakarta. 
Previous Research

Table 2.

Previous Research

\begin{tabular}{|c|c|c|c|c|c|c|}
\hline $\begin{array}{l}\text { N } \\
\text { o. }\end{array}$ & Title & Researcher & Description & $\begin{array}{l}\text { Research } \\
\text { Method }\end{array}$ & $\begin{array}{l}\text { Analysis } \\
\text { Method }\end{array}$ & Conclusion \\
\hline 1. & $\begin{array}{l}\text { Implementat } \\
\text { ion of NFC } \\
\text { as the Media } \\
\text { of Mobile- } \\
\text { based } \\
\text { Payment } \\
\text { Transaction } \\
\text { (2013) }\end{array}$ & $\begin{array}{l}\text { Violitta } \\
\text { Yesmaya } \\
\text { Dion } \\
\text { Darmaw } \\
\text { an }\end{array}$ & $\begin{array}{l}\text { Cash } \\
\text { payment is } \\
\text { replaced by } \\
\text { electronic } \\
\text { payment } \\
\text { based on } \\
\text { Near Field } \\
\text { Communicat } \\
\text { ion that is } \\
\text { due to the } \\
\text { guaranteed } \\
\text { safety. } \\
\text { (Yesmaya \& } \\
\text { Darmawan, } \\
\text { 2013). }\end{array}$ & $\begin{array}{l}\text { Qualitati } \\
\text { ve } \\
\text { Approac } \\
\text { h } \\
\text { Method }\end{array}$ & $\begin{array}{l}\text { Using an } \\
\text { income } \\
\text { presupposit } \\
\text { ion result of } \\
\text { NFC on } \\
\text { Global } \\
\text { Market }\end{array}$ & $\begin{array}{l}\text { NFC (Near } \\
\text { Field } \\
\text { Communicati } \\
\text { on) in } \\
\text { Indonesia is } \\
\text { one of the } \\
\text { efficient } \\
\text { devices in } \\
\text { doing a } \\
\text { payment } \\
\text { transaction } \\
\text { especially a } \\
\text { quick } \\
\text { ticketing in } \\
\text { the process. } \\
\text { By NFC, the } \\
\text { payment } \\
\text { transaction } \\
\text { process is } \\
\text { more } \\
\text { secured. }\end{array}$ \\
\hline 2. & $\begin{array}{l}\text { Payment } \\
\text { Application } \\
\text { System } \\
\text { Electronic } \\
\text { Payment on } \\
\text { Point of } \\
\text { Sales (POS) } \\
\text { based on } \\
\text { Near Field } \\
\text { Communicat } \\
\text { ion (NFC) } \\
\text { (2016) }\end{array}$ & $\begin{array}{l}\text { Saeful } \\
\text { Bahri, } \\
\text { Satia } \\
\text { Suhada }\end{array}$ & $\begin{array}{l}\text { NFC } \\
\text { Technology } \\
\text { Research is } \\
\text { one of } \\
\text { payment } \\
\text { media } \\
\text { alternative } \\
\text { to increase } \\
\text { flexibility in } \\
\text { business } \\
\text { process } \\
\text { especially } \\
\text { for selling } \\
\text { system or } \\
\text { point of } \\
\text { sales (Bahri } \\
\& \text { Suhada, } \\
\text { 2016). }\end{array}$ & $\begin{array}{l}\text { Qualitati } \\
\text { ve } \\
\text { Approac } \\
\text { h } \\
\text { Method }\end{array}$ & $\begin{array}{l}\text { Using a } \\
\text { payment } \\
\text { system plan } \\
\text { of NFC } \\
\text { then it is } \\
\text { implemente } \\
d \text { in Point } \\
\text { of Sales }\end{array}$ & $\begin{array}{l}\text { Electronic } \\
\text { payment } \\
\text { system } \\
\text { should be } \\
\text { used as a } \\
\text { main device } \\
\text { because it } \\
\text { makes it easy } \\
\text { to do } \\
\text { transaction. }\end{array}$ \\
\hline
\end{tabular}


Table 2, Cont.

Previous Research

\begin{tabular}{|c|c|c|c|c|c|c|}
\hline 3 & $\begin{array}{l}\text { Secure Bus- } \\
\text { Ticketing } \\
\text { System Using } \\
\text { NFC (2015) }\end{array}$ & $\begin{array}{l}\text { Monalis } \\
\text { a Lopes, } \\
\text { Grishm } \\
\text { a Shah, } \\
\text { Nandini } \\
\text { Vyas, } \\
\text { Saloni } \\
\text { Shetye, } \\
\text { Sohaga } \\
\text { ni Shah }\end{array}$ & $\begin{array}{l}\text { Making the } \\
\text { day to day life } \\
\text { more } \\
\text { convenient for } \\
\text { the passengers } \\
\text { travelling in } \\
\text { bus some } \\
\text { technologies } \\
\text { can be done by } \\
\text { using like } \\
\text { Near Field } \\
\text { Communicati } \\
\text { on (NFC), } \\
\text { Radio Frequency } \\
\text { Identification } \\
\text { (RFID) } \\
\text { (Lopes, Shah, } \\
\text { Vyas, Shetye, } \\
\text { \& Shah, } \\
\text { 2015). }\end{array}$ & $\begin{array}{l}\text { Qualitative } \\
\text { Approach } \\
\text { Method }\end{array}$ & $\begin{array}{l}\text { Looking at } \\
\text { how it } \\
\text { works from } \\
\text { NFC } \\
\text { System } \\
\text { then } \\
\text { looking at } \\
\text { flowchart } \\
\text { design } \\
\text { from NFC } \\
\text { System. }\end{array}$ & $\begin{array}{l}\text { NFC } \\
\text { tickets help } \\
\text { in } \\
\text { identifying } \\
\text { people } \\
\text { travelling } \\
\text { in the bus } \\
\text { providing } \\
\text { security. }\end{array}$ \\
\hline 4 & $\begin{array}{l}\text { Application of } \\
\text { Near Field } \\
\text { Communication } \\
\text { Technology } \\
\text { for Mobile } \\
\text { Airline } \\
\text { Ticketing } \\
(2012)\end{array}$ & $\begin{array}{l}\text { Wayan } \\
\text { Suparta }\end{array}$ & $\begin{array}{l}\text { The study } \\
\text { describes the } \\
\text { characteristics } \\
\text { and } \\
\text { advantages of } \\
\text { NFC } \\
\text { technology } \\
\text { offers for the } \\
\text { development } \\
\text { of mobile } \\
\text { airline } \\
\text { ticketing } \\
\text { (Suparta, } \\
\text { 2012) }\end{array}$ & $\begin{array}{l}\text { Qualitative } \\
\text { Approach } \\
\text { Method }\end{array}$ & $\begin{array}{l}\text { By } \\
\text { checking in } \\
\text { and } \\
\text { checking } \\
\text { out } \\
\text { description } \\
\text { at } \\
\text { Internation } \\
\text { al Airport } \\
\text { Yogyakarta. }\end{array}$ & $\begin{array}{l}\text { NFC } \\
\text { System is } \\
\text { impossible } \\
\text { for not } \\
\text { realizing } \\
\text { NFC } \\
\text { Technology } \\
\text { in } \\
\text { Internation } \\
\text { al Airport } \\
\text { Yogyakarta, } \\
\text { at least in } \\
\text { the new } \\
\text { airport } \\
\text { location in } \\
\text { Kulon } \\
\text { Progo, } \\
\text { Yogyakart } \\
\text { a. }\end{array}$ \\
\hline
\end{tabular}

\section{Literatur Review}

\section{Near Field Communication}

NFC is based on standard, short distance, near-cable connectivity technology that enable two simple and intuitive ways among Electronic Device (NFC Forum, 2011). Near Field Communication (NFC) can make the s' life easier and more comfortable by making it easier to do transaction, exchange digital content and connect their electronic device only by touching. 
NFC designed to build RFID by enabling a complex exchanging among the direct participants can be operated in a few models. Communication model is differentiated whether the device creates communication model by its own power or the device takes the power from a field is resulted by other device. If a device results in its own field, then it is called an active device, if it doesn't, it is called a passive device. An active device usually has supply power (smartphone), but a passive device usually doesn't.

Near Field Communication Technology has been applied in many developed countries. The advantage of this technology is the wireless communication that has a short enough distance and communication can go on quickly. This superiority can reduce the security problem risk that becomes the biggest problem in mobile communication technology. The relatively close communication distance is disabled if there is a man-in-themiddle attack (a third side that steals or changes the data) or eavesdropping (tapping of data). The existence of an attack is probably smaller than using other communication. Near-field communication technology itself can be applied to all kinds of application models such as: payment media (ticketing/ micro payment), smart board for university, contactless token, and device pairing (device communication). Below is the description of Near Field Communication System Architecture:

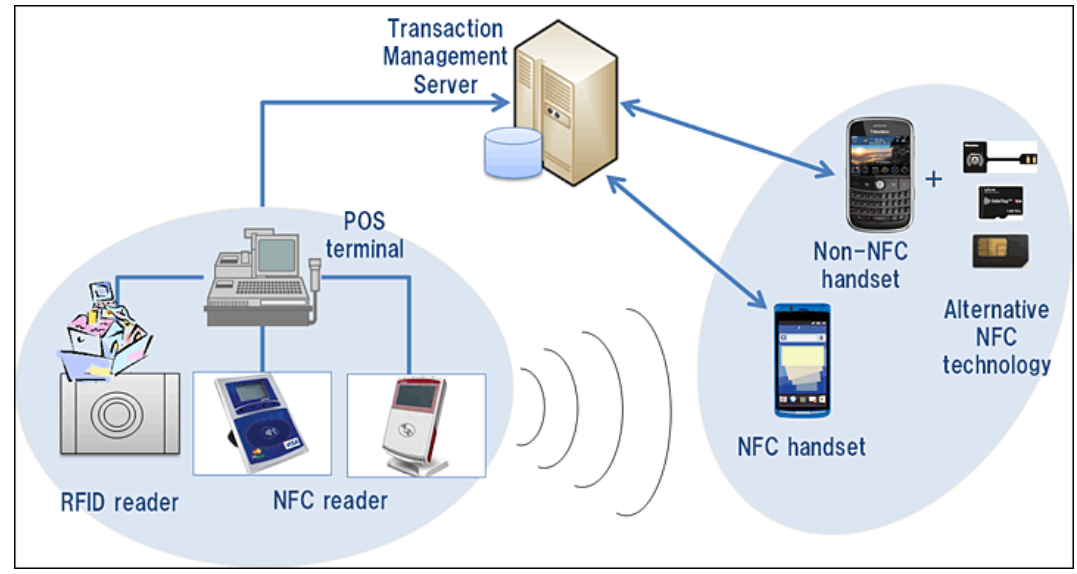

Figure 2. Near Field Communication System

Source: http://www.nttdata.com/global/en/newscenter/pressrelease/2012/032900.html 


\section{Method}

The used research method is qualitative method where qualitative research investigates participants' perspective by flexible and interactive strategies. Qualitative Research is referred to understanding a social phenomenon from a viewpoint of the participants. Therefore, qualitative research is a research that is used to research the natural condition of the object where researcher is the instrument of key (Sugiyono, 2013). There are some methods of collecting data in qualitative research, which are interview method, observation method, documentation method and literature study method.

\section{Result and Discussion}

\section{Benefit of Technology on Transportation}

Social media and information service have substantial role for transportation users in knowing current traffic condition (K.; M.; S. Martono, 2002). The benefits of technology have been advanced and developed. So far, public transportation payment has been done by an electronic card. Moreover, the reservation of a long distance ticket for public transportation is done online. In the last five years, the most country with the increase internet users is the Philippine, in which it has increased for 531 percent. The second is Indonesia with 430 percent, followed by South Africa and India (Global Web Index, 2013). NFC System itself also has started developing in Indonesia. However, until now, Indonesia hasn't showed any kind of international reports as other countries which use NFC. Telkomsel Channel Management states that they want to do a test on NFC. NFC Device from Telkomsel has been installed in Circle-K Kelapa Gading. Nevertheless, there is no official statement from Telkomsel related to the technology adoption. Even though operators haven't organized NFC yet, some local application makers have been ready to enliven the presence of this technology. For example, Menoo! TAP Tap, and Smash Mania are ready to support NFC Nokia. InTouch also has been ready to provide NFC application for Blackberry user. 


\section{Public Transportation Payment in Indonesia}

Indonesia has been using electronic card as a payment system for public transportation payment. Almost all public transportation in Jakarta has been using an electronic card, such as Trans Jakarta and Commuter Line. Below is the payment system for Commuter Line and Trans Jakarta:

\section{Trans Jakarta}

The payment system:

1. Ticket card is tapped on the machine that is located in the gate of the bus shelter.

2. If the balance is sufficient, the green light on the gate will be turned on, and the gate will be opened. If the balance is not enough, the passenger can top up or refill the balance in the ticket counter with nominal starts from $\mathrm{Rp}$ 10.000. The top up can be done using cash, debit card, or through ATM Machine.

3. At the destination shelter, the passenger must tap back on the gate to go out.

4. The card will not be expired if there is still balance left on it.

5. The card can be used like a debit card. It can be used to shop in the stores that cooperate with the bank that serve payment using it.

6. The card can be used by more than 1 person in a day with flat tariff of Rp. 3.500 .

\section{Commuter Line}

Commuter Line has 2 types of card for payment; daily ticket (THB) and Multi Trip Card (KMT).

Daily ticket card system:

1. Daily ticket card (THB) works by deposit. It will not prevail if a passenger only taps through the entrance and doesn't go out through an official gate.

2. A passenger can't use the ticket back as well as get the deposit back if the ticket is broken or can't be read in KRL e-ticketing system.

3. The deposit can be retrieved if the passenger cancels the trip and hasn't done tapping in to gate in yet. 
4. The deposit will be given back without tariff if a passenger cancels the trip but has gone into the gate in.

Multi Trip Card (KMT) system:

1. KMT only can be used for Commuter Line transportation facility.

2. KMT can be transferred to a person who is not a previous owner.

3. KMT for Commuter Line can't be used for 2 persons in once tapping.

4. There is no expiry date for KMT, and the minimal balance is Rp 14.000.

5. KMT that is lost or stolen can't be blocked like ATM. Everything that happens to KTM is the responsibility of the card owner.

\section{NFC Comparison with Other Technology}

It can be seen that Indonesia has been using electronic card instead of NFC for the public transportation. The table below shows the difference between using electronic card and NFC:

Table. 3. NFC Comparison with Electronic Card

\begin{tabular}{|c|c|c|}
\hline No. & Near Field Communication & Electronic Card \\
\hline 1 & $\begin{array}{l}\text { It is easy to do transaction without using } \\
\text { credit or prepay card. It can be done only } \\
\text { by using smartphone that is integrated } \\
\text { with NFC. }\end{array}$ & $\begin{array}{l}\text { The balance can be topped up in the } \\
\text { ATM Machine or in the counter that } \\
\text { is available and passengers must } \\
\text { queue. }\end{array}$ \\
\hline 2 & $\begin{array}{l}\text { The connection with other devices is } \\
\text { easy, with only one touch. The NFC } \\
\text { frequency is stronger than Bluetooth. }\end{array}$ & $\begin{array}{l}\text { It can't be well detected if there are } \\
\text { more than } 1 \text { RFID chips in one card. }\end{array}$ \\
\hline 3 & $\begin{array}{l}\text { It is safer and more comfortable because } \\
\text { NFC has a good security system }\end{array}$ & $\begin{array}{l}\text { It is not equipped by pin and the } \\
\text { name of the owner is not printed. So, } \\
\text { it is easy to be accidentally } \\
\text { exchanged or lost. Also, the } \\
\text { procedure to get the money back is } \\
\text { difficult. }\end{array}$ \\
\hline 4 & The checking of the balance is faster. & $\begin{array}{l}\text { The transaction is faster but the } \\
\text { checking of the balance is not really } \\
\text { efficient because it must be checked } \\
\text { every day in a special machine. }\end{array}$ \\
\hline
\end{tabular}


Table 4. NFC Comparison with Short Distance Communication Technology

\begin{tabular}{|c|c|c|c|c|}
\hline & NFC & RFID & IrDA & Bluetooth \\
\hline $\begin{array}{l}\text { Setup } \\
\text { Time }\end{array}$ & $<0.1 \mathrm{~ms}$ & $<0.1 \mathrm{~ms}$ & $\sim 0.5 \mathrm{sec}$ & $\sim 6 \mathrm{sec}$ \\
\hline Range & $\mathrm{Up}$ to $10 \mathrm{~cm}$ & Up to $3 \mathrm{~m}$ & Up to $5 \mathrm{~m}$ & Up to $30 \mathrm{~m}$ \\
\hline Usability & $\begin{array}{l}\text { Human centric, } \\
\text { easy, intuitive, fast }\end{array}$ & $\begin{array}{l}\text { Item } \\
\text { centric, } \\
\text { easy }\end{array}$ & $\begin{array}{l}\text { Data } \\
\text { centric, } \\
\text { easy }\end{array}$ & Data centric, medium \\
\hline Selectivity & $\begin{array}{l}\text { High, given, } \\
\text { security }\end{array}$ & Partly given & $\begin{array}{l}\text { Line of } \\
\text { sight }\end{array}$ & - \\
\hline Use Cases & $\begin{array}{l}\text { Pay, get access, } \\
\text { share, } \\
\text { service, easy set up }\end{array}$ & $\begin{array}{l}\text { Item } \\
\text { Tracking }\end{array}$ & $\begin{array}{l}\text { Control } \\
\text { and } \\
\text { exchange } \\
\text { data }\end{array}$ & $\begin{array}{l}\text { Network for data } \\
\text { exchange, headset }\end{array}$ \\
\hline $\begin{array}{l}\text { Consumer } \\
\text { Experience }\end{array}$ & $\begin{array}{l}\text { Touch, wave and } \\
\text { simple, connect }\end{array}$ & $\begin{array}{l}\text { Get } \\
\text { information }\end{array}$ & Easy & Configuration needed \\
\hline
\end{tabular}

Source: (Suparta, 2012)

\section{NFC Application in Some Countries}

Near Field Communication Application has been implemented for public transportation in some cities in other countries. They are:

1. London - NFC Mobile Phones.

In 2007, London did a test for transportation ticket payment through NFC and mobile phone. The cost offered was from the highest to the lowest. The transport authority in London has cooperated with companies such as O2, Nokia, Barclaycard, and Visa. Cooperation was done to examine the 's request to be able to have an easy card to be brought and used such as; Oyster card, (Transportation Card of UK), or Credit card that is available in Nokia 613.

2. San Francisco - NFC Mobile Phones

In 2008, VIVO-tech, a non-cash payment system provider activated the test for mobile payment of NFC BART (Bay Area Rapid Transit) in San Francisco. BART cooperated with Sprint, First Data, and fast food Jack in the Box to enable hundreds of passengers get on BART only by using their NFC cellphone in the gate to get an access in the station.

3. Frankfurt - NFC for Public Transportation 
On July to November, 2007, Transportation Institute in Germany Rhein-Main-Verkehrsverbund GmbH (RMV) tested RMV-HandyTicket für NFC-Handys in Frankfurt. The device used was mobile phone with Java application. In that test, the most visited 59 shelters were equipped with NFC radio chip (ConTag). Around 270 costumers examined the ticket system. Besides buying ticket, the costumer also could call the departure schedule in a certain shelter with their NFC phones and get the real time information through ConTag.

Table 5. Advantages and Disvantage on a Payment System

\begin{tabular}{|c|c|c|c|}
\hline No. & System & Advantages & Disvantages \\
\hline 1. & $\begin{array}{l}\text { NFC and mobile } \\
\text { phone }\end{array}$ & $\begin{array}{l}\text { - Costumer is interested in } \\
\text { using mobile phone to } \\
\text { reserve ticket } \\
\text { - Ticket can easily be } \\
\text { reserved online }\end{array}$ & $\begin{array}{l}\text { - Requires a sophisticated } \\
\text { mobile phone system } \\
\text { - TFL only cooperates with } \\
\text { the Nokia, O2, } \\
\text { Barclaycard, and Visa }\end{array}$ \\
\hline 2. & $\begin{array}{l}\text { RMV }- \text { Handy } \\
\text { Ticket } \quad \text { (Mobile } \\
\text { Ticket). }\end{array}$ & $\begin{array}{l}\text { - Helps the costumer find } \\
\text { the shelter } \\
\text { - Gives the delay } \\
\text { information of quickly } \\
\text { - Uses a debit, so it is easy } \\
\text { and quick } \\
\text { - Individual journey } \\
\text { invoice is available }\end{array}$ & $\begin{array}{l}\text { - The cost can only be } \\
\text { retrieved at the end of the } \\
\text { month } \\
\text { - Requires a high power } \\
\text { mobile phone system } \\
\text { - The result of research only } \\
\text { came from } 270 \text { costumers } \\
\text { that examined the ticket } \\
\text { system }\end{array}$ \\
\hline
\end{tabular}

\section{NFC Technology Adoption Potential}

Near Field Communication makes the payment system easy and simple where the data is exchanged through near cable by a short distance between devices. Near Field Communication is also a connectivity technology device based on RFID (Radio Frequency Identification) technology that makes a payment system through smartphone. Some Near Field Communication (NFC) Technology adoption potential are :

1. Public transportation service payment : Trans Jakarta, Commuter Line 2. Banking : ATM, Visa. 
3. Loyalty + e-Coupon: Community card or membership that provides discount and coupon for loyal members by certain rules.

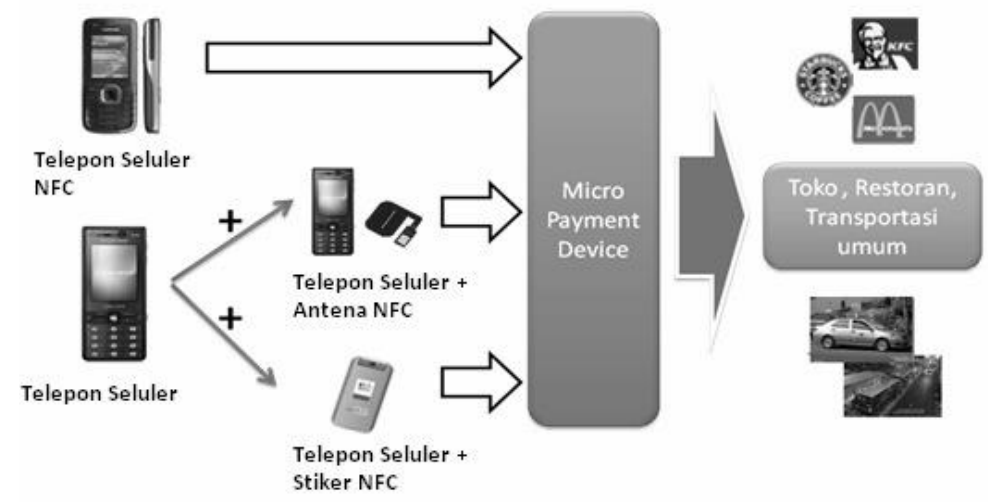

Figure. 3. Mobile Phone Optimization for Micro Payment

Source : (Krisnanda, 2011)

The superiority possessed by NFC is its role as a technology that makes it easy for costumer to open any kind of communication and transaction. NFC enables costumer to do things only by touching or putting their smartphone device near the service that they need. NFC should be adopted for future public transportation in Jakarta because it will make it easy for passengers to buy ticket and it will reduce the queue for topping up the balance. By using this system, passengers can easily top up the balance through m-Banking and it is integrated directly. Almost all people have smartphone these days, so it is very possible to use this NFC system in Indonesia, especially in Jakarta. In the future, NFC keeps making innovation in developing its technology. NFC development is divided into 3 categories. For the airlines, a tariff that is too low may jeopardize the sustainability of an air carrier's operations, while a tariff is too expensive may make it unaffordable for travelers to travel They are service initiation, peer to peer and ticketing payment. The applying of Near Field Communication can be realized for public transportation payment system : 
Figure 4. Applying NFC on Public Transportation

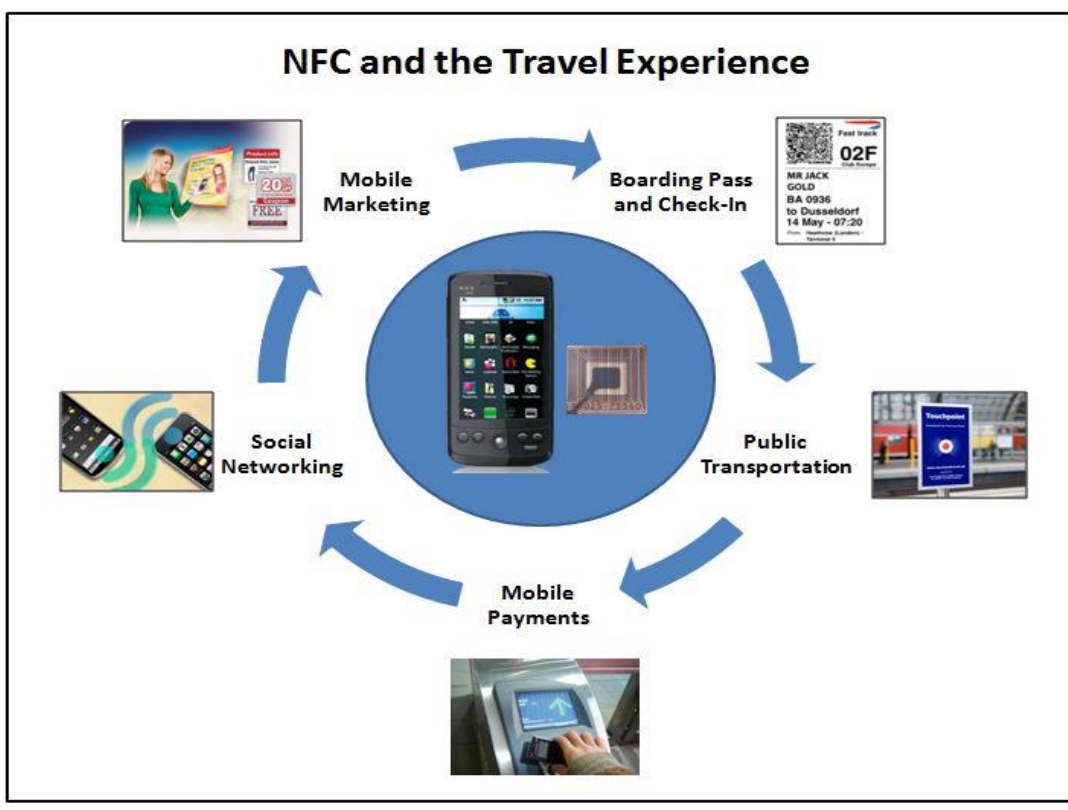

Source : (Traveltechnology.com, 2011)

\section{Conclusion}

Based on what has been discussed above, there are some conclusions that can be drawn:

1. The utilization of NFC System Technology is really feasible because it can be used by the passengers. NFC system can do a data exchange with near cable by a short distance between devices. Besides, this NFC system is safer and more comfortable to be used because of its security system. NFC is designed for the easiness of public transportation payment and therefore should be applied in DKI Jakarta.

2. NFC System has given the easiness of payment system in transportation activity in London, San Francisco, and Frankfurt. The methods of applying the system are various, but resulting in the easiness for the people to use public transportation. NFC is better than electronic card.

3. Because of its superiority, NFC system adoption is potential for the future use for public transportation in Jakarta. It makes it easy and comfortable for costumer to open any kind of communication and transaction model. 


\section{References}

Bahri, S., \& Suhada, S. (2016). Penerapan Sistem Pembayaran Secara Elektronik Pada Point of Sales (P.O.S) Berbasis Near Field Communication (NFC). Seminar Nasional Ilmu Pengetahuan Dan Teknologi Komputer, (4(1)), 258-261.

BPS Provinsi DKI Jakarta. (2016). Jakarta Dalam Angka 2016. (Y. Rochadiyat, Ed.). Jakarta: BPS Provinsi DKI Jakarta. Retrieved from https://jakarta.bps.go.id/backend/pdf_publikasi/Jakarta-Dalam-Angka2016.pdf

Global Web Index. (2013). No Title. Retrieved from https://www.globalwebindex.net/

Kadarisman, M., Gunawan, A., \& Ismiyati, I. (2017). Kebijakan Manajemen Transportasi Darat Dan Dampaknya Terhadap Perekonomian Masyarakat Di Kota Depok. Jurnal Manajemen Transportasi Dan Logistik, 3(1), 41. https://doi.org/10.25292/j.mtl.v3i1.140

Krisnanda, M. (2011). Penggunaan Teknologi Near Field Communication Pada Telepon Seluler Untuk Micro Payment dan Loyalty Management. Jurnal Informatika, 7, 27-37.

Lopes, M., Shah, G., Vyas, N., Shetye, S., \& Shah, S. (2015). Secure BusTicketing System Using Nfc, 5(4), 43-45.

Martono, K. ; M. ; S. (2002). An Analysis Of The Lack Of Social Media Access And Information Service By Ctc ( Cawang-, 106-108.

Martono, K., \& Marina, S. (n.d.). Domestic Air Transport Regulations in Indonesia, 3(1), 1-19.

NFC Forum. (2011). NFC in Public Transport. NFC Forum, (January), 33. Retrieved from http://www.nfcforum.org/resources/white_papers/NFC_in_Public_Transport.pdf

Rafi, S., \& Rifni, M. (n.d.). Soft Systems Methodology Pada Pengembangan Bandar Udara Provinsi Sulawesi Barat Soft System Methodology-Based on Development of Airport of West Sulawesi, 4(2), 159-176.

Siregar, S. R., Manajemen, S. T., Trisakti, T., Manajemen, S. T., \& Trisakti, T. (n.d.). Implementasi Kebijakan Transportasi Publik Lalu Lintas Di Medan the Implementation of Public Transportation Policy on Solving Traffic Density and, 4(2), 147-158.

Sugiyono. (2013). Metode Penelitian Manajemen. Alfabeta, 820. https://doi.org/10.1177/004057368303900411

Suparta, W. (2012). Application of Near Field Communication Technology for Mobile Airline Ticketing. Journal of Computer Science, 8(8), 12351243. https://doi.org/10.3844/jcssp.2012.1235.1243

Traveltechnology.com. (2011). Sentient Things and NFC. Retrieved from http://www.traveltechnology.com/2011/02/sentient-things-and-nfc/

Yesmaya, V., \& Darmawan, D. (2013). Implementasi NFC sebagai media untuk transaksi pembayaran berbasis mobile. Jurnal Teknik Dan Ilmu Komputer, 2(7), 280-286. 